\title{
Influence of Cold Working on Mechanical Properties of Al-SiC Composites
}

\author{
Stefan Szczepanik ${ }^{1, a^{*}}$, Piotr Nikiel ${ }^{1, b}$, Piotr Bednarczyk ${ }^{1, c}$ \\ ${ }^{1}$ AGH University of Science and Technology, Faculty of Metals Engineering and Computer \\ Industrial Science, al. Mickiewicza, 30-059 Krakow, Poland \\ aszczepan@metal.agh.edu.pl, ${ }^{\text {bp pnikiel@metal.agh.edu.pl, }{ }^{c} p b e d n a r @ a g h . e d u . p l ~}$
}

Keywords: powder metallurgy, particles reinforced composites, cold working, drawing

\begin{abstract}
The main objective of this research was a study on the simultaneous influence of cold working and particle reinforcement on the mechanical properties of aluminum. The model composites were fabricated by cold pressing of RAl-1 aluminum and $5 \%$ and $10 \% \mathrm{SiC}$ powders and hot extrusion with extrusion ratio 3.8 in isothermal conditions at $480^{\circ} \mathrm{C}$ with $90^{\circ}$ die angle to $18 \mathrm{~mm}$ diameter. Some specimens were then cold drawn with a linear velocity of $1 \mathrm{~m} / \mathrm{min}$ to $16 \%$ area reduction, and one specimen in 3 passes to $51 \%$ reduction in area. Mechanical properties of the near fully dense composites were determined by axial compression, bending tests and hardness measurement and their microstructure examined, showing near homogenous distribution of $\mathrm{SiC}$ particles in the aluminium matrix. The increase in Young's modulus (E) was from 67 to $74 \mathrm{GPa}$ and to $82 \mathrm{GPa}$ for $5 \%$ and $10 \%$ reinforcement, respectively. Drawing increased average yield strength from 70 to $100 \mathrm{MPa}$ for $\mathrm{Al}$, and from 74 to $110 \mathrm{MPa}$ and from 80 to $115 \mathrm{MPa}$, for 5 and $10 \%$ reinforcement, respectively. The results indicate that there is a significant increase in $\mathrm{E}$, in accordance with the law of mixtures, through incorporation of $\mathrm{SiC}$ and a synergistic effect of $\mathrm{SiC}$ and plastic deformation during drawing on strength. An attempt is made to identify the various contributions to overall strengthening of $\mathrm{Al}$ by considering also $\mathrm{Al}-8.8 \mathrm{Cu}-6.3 \% \mathrm{Si}-0.7 \mathrm{Mg}$ alloy. It appears that alloying and age-hardening have the greatest effect, but that contributions from hot, warm and cold working are not significant. As powder metallurgy processing is an important fabrication method, their incorporation into the processing schedule merits consideration.
\end{abstract}

\section{Introduction}

Silicon carbide particulate reinforcement of aluminium and its alloys is used generally to increase Young's modulus and wear resistance. Techniques employed include cold pressing and sintering [1], hot isostatic pressing HIP [2], stir casting and rheo-casting [3], vacuum hot pressing [4], spray forming [5], thixoforming [6] and other [9]. Strengthening in hot and warm forged and extruded composites has received special attention [7,8,10]. Closed-die forged $\mathrm{Al}-5 \% \mathrm{SiC}$ and hot extruded $\mathrm{Al}-8.8 \mathrm{Cu}-6.3 \% \mathrm{Si}-0.7 \mathrm{Mg}$ alloy were investigated. To obtain more precise input for the individual compositional and microstructural contributions to the overall strength, it is now reported about the influence of a further postextrusion operation, cold drawing, using model systems for Al-5 and $10 \% \mathrm{SiC}$ particles.

Composites fabrication. Powders of aluminium RAl-1 (99.7 wt.-\% of Al) with 5 and 10 weight-\% $\mathrm{SiC}$, with particles grit size $250 \mu \mathrm{m}$, were ground in a ball mill for 1 hour. Preforms were cold unilaterally pressed on a hydraulic press ZD100, at ambient temperature under $80 \mathrm{MPa}$ with die diameter $35.3 \mathrm{~mm}$. The preforms were heated at $480^{\circ} \mathrm{C}$ before hot extrusion, with the extrusion ratio (defined by starting cross-sectional area divided by the final cross-sectional area) 3.8 to a diameter $18 \mathrm{~mm}$. Some specimens were turned to $17.5 \mathrm{~mm}$ diameter before drawing. Drawing was done on a carriage drawing machine at linear speed of $1 \mathrm{~m} / \mathrm{min}$ with a $16 \mathrm{~mm}$ diameter drawing die to $16.4 \%$ reduction in area. Figure 1 shows the shape of specimens during processing (with one step drawing) of aluminium material from powder. The microstructure and properties by means of hardness, compression and bend tests were examined of extruded and drawn materials. 


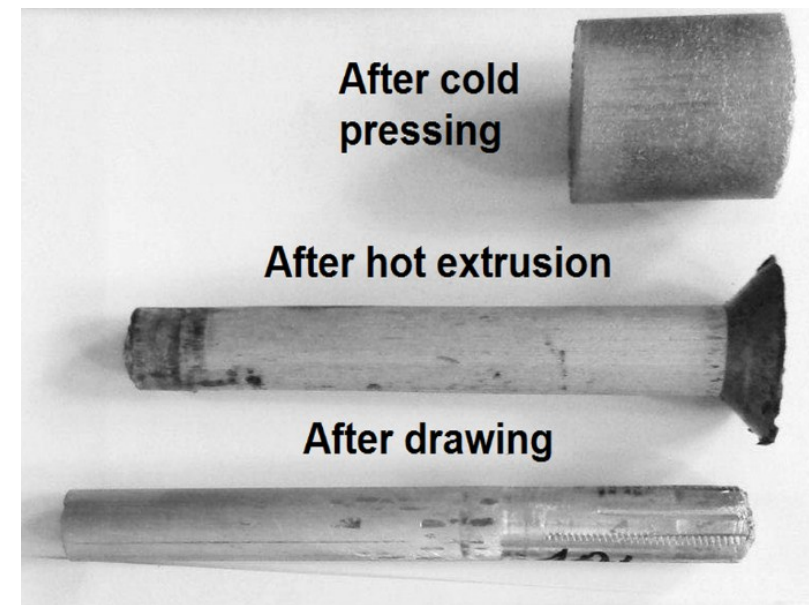

Fig. 1. Processing steps of aluminium

Microtructural examinations. Metallographic studies using optical microscopy, Leica DM4000M and Zeiss Axio Imager M1m, and scanning electron microscopy, Hitachi S-3500N, were carried out on as-fabricated and fractured specimens.

Compression and bend tests. Compression and bend tests were conducted on an Instron 1196 machine with a traverse speed of $5 \mathrm{~mm} / \mathrm{min}$. Axial compression was performed on specimens with height $16 \mathrm{~mm}$ and diameter $16 \mathrm{~mm}$. For bend testing the span was $60 \mathrm{~mm}$ for $16 \mathrm{~mm}$ diameter specimens.

Hardness testing. Brinell hardness was measured with a force of $153.2 \mathrm{~N}$.

a)
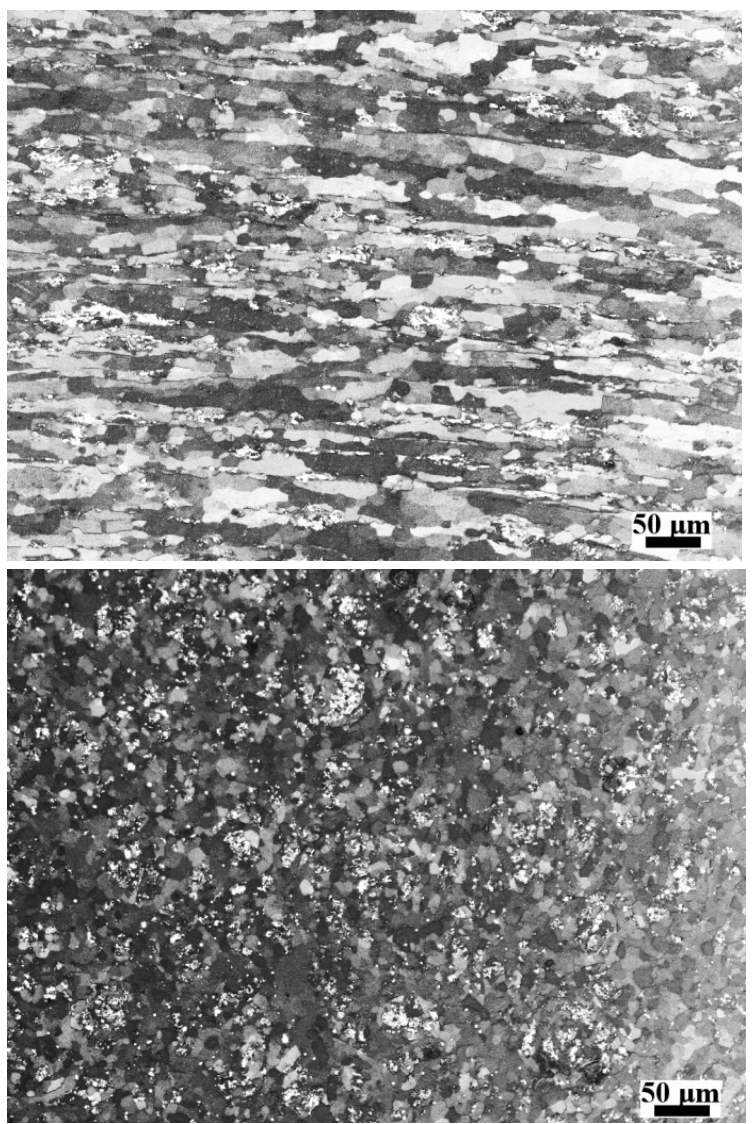

b)

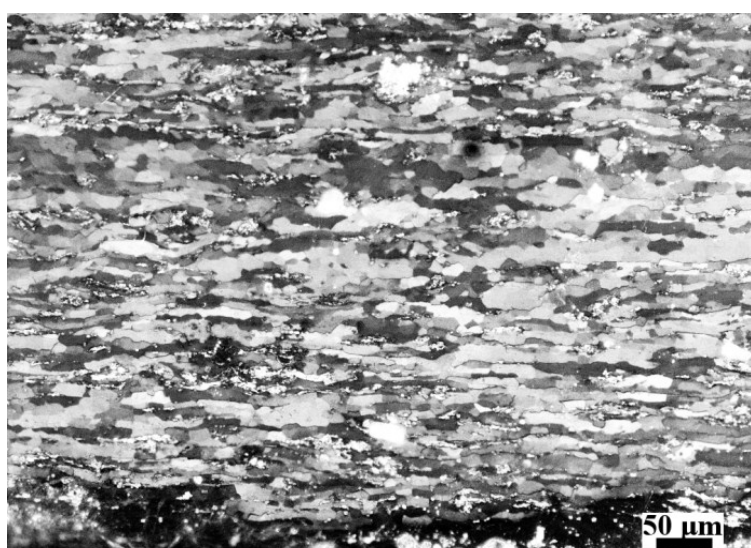

d)

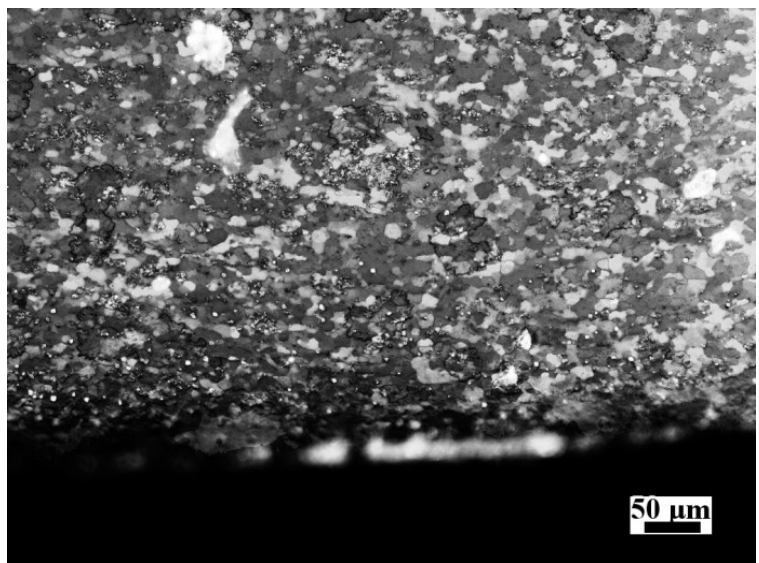

Fig. 2. Microstructures of hot extruded aluminium (at $480^{\circ} \mathrm{C}$, extrusion ratio 3.8) on the: a), b) longitudinal section; c), d) cross section. Magnification: a), c) 100x, b), d) 200x. Zeiss microscope, etched. Observation sites: a), c) $-0.5 \mathrm{~mm}$ from outer surface; b), c) - near outer surface 


\section{Results}

Microstructures of $\mathrm{Al}$ and $\mathrm{Al}-\mathrm{SiC}$ composites. Examples of metallographic observations, as revealed by Barker reagent, on Zeiss Axio Imager $\mathrm{M} 1 \mathrm{~m}$ microscope using polarized light are presented in Fig. 2. As a result of extrusion the grains became elongated in the direction of material flow (Fig. 2a, 2b). The microstructure observed on cross section on Figures $2 \mathrm{c}$ and $2 \mathrm{~d}$ is formed of small, nearly globular shaped grains. Fig. 3 shows the unetched microstructure of composite materials observed on the Leica microscope. Uniform distribution of pockets of SiC particles (dark regular shape), fine oxides and small porosity in the aluminium matrix are visible. More uniform distribution of $\mathrm{SiC}$ particle appears in $\mathrm{Al}-10 \% \mathrm{SiC}$ structure.

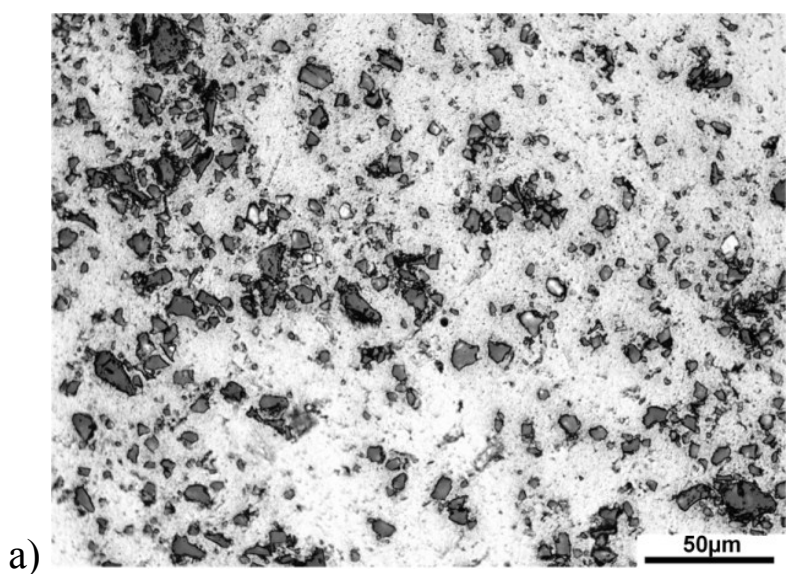

b)

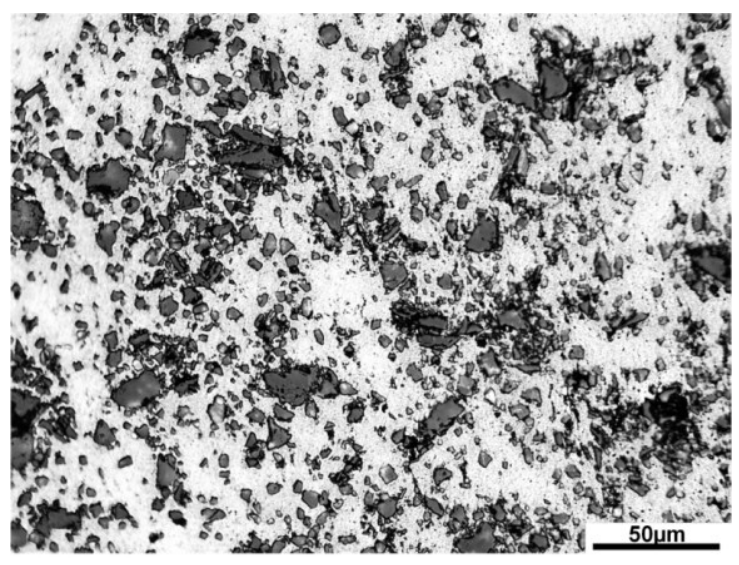

Fig. 3. Microstructures of hot extruded (at $480^{\circ} \mathrm{C}$, extrusion ratio 3.8) and drawn (from diameter 17.5 to $16 \mathrm{~mm}$ ) composites: a) $\mathrm{Al}-5 \% \mathrm{SiC}$, b) $\mathrm{Al}-10 \% \mathrm{SiC}$, Leica microscope, unetched, magnification $500 \mathrm{x}$

a)

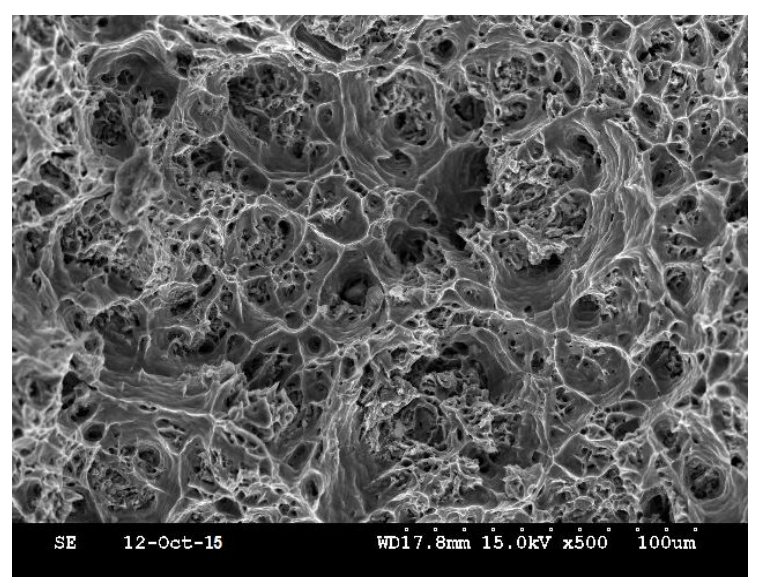

b)
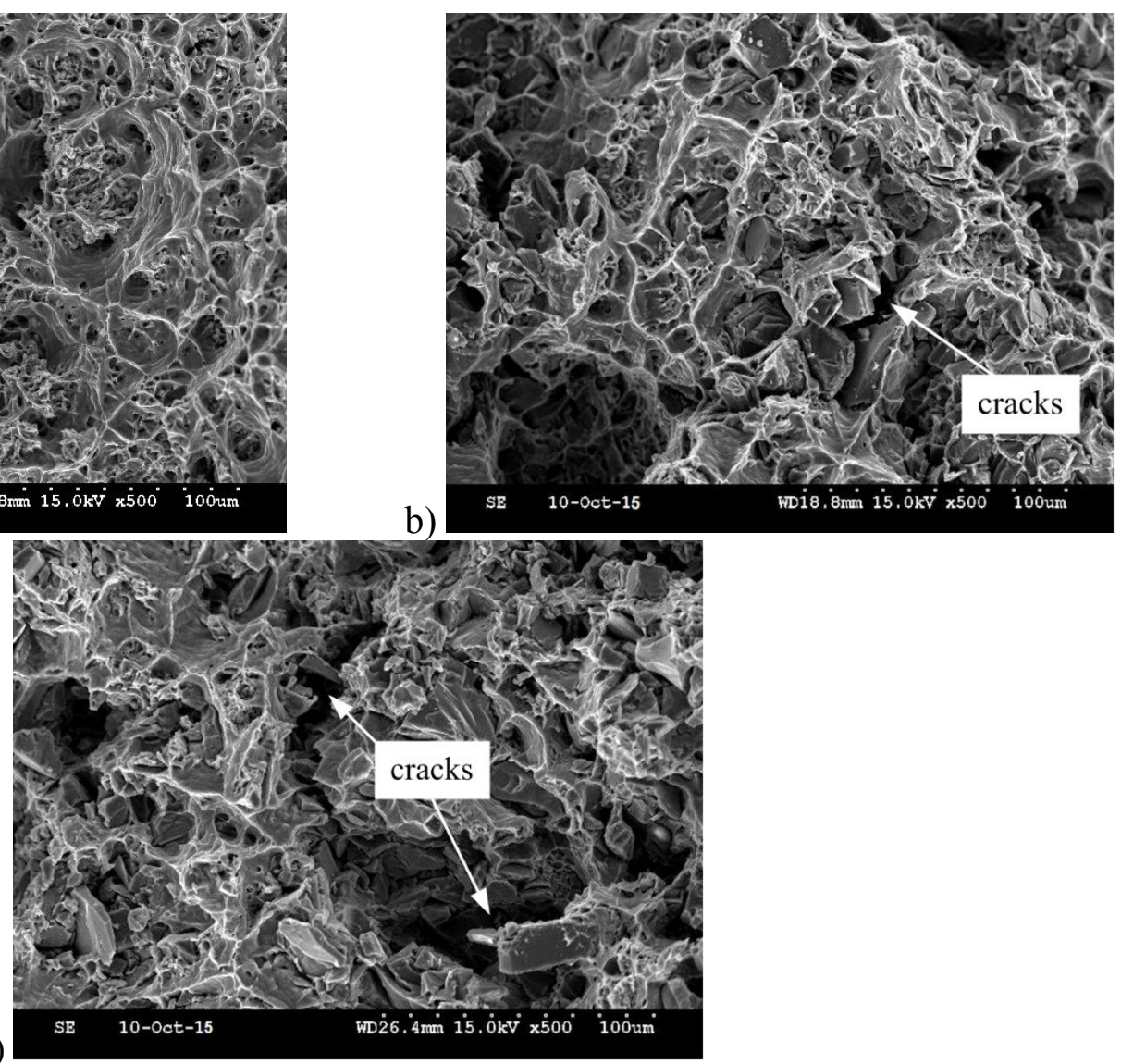

Fig. 4. SEM fractures: a) Al, b) Al-5\% $\mathrm{SiC}$, c) $\mathrm{Al}-10 \% \mathrm{SiC}$ after hot extrusion at $480^{\circ} \mathrm{C}$ with 4.2 ratio 
Small particles of $\mathrm{SiC}$ were observed on fracture images of failed bend specimens acting as stress concentrators for cracking (Fig. 4b, c). Al matrix fracture surfaces were ductile. In fractures of $\mathrm{Al}-10 \% \mathrm{SiC}$ composite small brittle sites around the $\mathrm{SiC}$ particles appeared.

Properties. The density of hot extruded specimens was $2.65 \mathrm{~g} / \mathrm{cm}^{3}$ for aluminium and $2.67 \mathrm{~g} / \mathrm{cm}^{3}$ for Al-SiC composites. Young's modulus, yield stress and hardness data are summarised in Table 1. Almost $30 \%$ increases in hardness were obtained as a result of one pass drawing. Young's modulus increased with $\mathrm{SiC}$ content in accordance with the law of mixtures. Yield strength increased with $\mathrm{SiC}$ content, extrusion and drawing (Table 2). For extruded materials the reinforcing SiC particles have only a small influence on the yield stress. Fig. 5 shows the compressive stress - logarithmic strain and Fig. 6 the bending moment vs displacement plots.

Table 1. Mechanical properties of aluminium and Al-SiC composites

\begin{tabular}{|c|c|c|c|c|c|}
\hline \multirow{2}{*}{ Material } & \multirow{2}{*}{ Process } & \multirow{2}{*}{\begin{tabular}{|c|} 
Young's \\
modulus [GPa] \\
Compression \\
\end{tabular}} & \multicolumn{2}{|c|}{ Yield stress [MPa] } & \multirow{2}{*}{$\begin{array}{c}\text { Hardness } \\
{[\mathrm{HB}]}\end{array}$} \\
\hline & & & Compression & Bend & \\
\hline $\mathrm{Al}$ & \multirow{3}{*}{ Extrusion } & $67 \pm 4$ & $70 \pm 3$ & $65 \pm 5$ & $23 \pm 1$ \\
\hline $\mathrm{Al}-5 \% \mathrm{SiC}$ & & $74 \pm 4$ & $74 \pm 3$ & $73 \pm 5$ & $27 \pm 1$ \\
\hline $\mathrm{Al}-10 \% \mathrm{SiC}$ & & $82 \pm 1$ & $80 \pm 3$ & $87 \pm 5$ & $28 \pm 1$ \\
\hline $\mathrm{Al}$ & \multirow{3}{*}{$\begin{array}{c}\text { Extrusion and } \\
\text { drawing } \\
(1 \text { pass })\end{array}$} & $67 \pm 2$ & $100 \pm 3$ & $104 \pm 5$ & $31 \pm 1$ \\
\hline $\mathrm{Al}-5 \% \mathrm{SiC}$ & & $82 \pm 3$ & $110 \pm 3$ & $119 \pm 5$ & $34 \pm 1$ \\
\hline $\mathrm{Al}-10 \% \mathrm{SiC}$ & & $95 \pm 3$ & $117 \pm 3$ & $126 \pm 5$ & $36 \pm 1$ \\
\hline $\mathrm{Al}-5 \% \mathrm{SiC}$ & $\begin{array}{l}\text { further } \\
2 \text { passes }\end{array}$ & - & $150 \pm 3$ & - & - \\
\hline
\end{tabular}

Table 2. Influence of $\mathrm{SiC}$ addition on yield stress and apparent bend strength for RAl-1, and for Al-8.8Cu-6.3\% $\mathrm{Si}-0.7 \mathrm{Mg}$ alloy [10]

\begin{tabular}{|c|c|c|c|c|c|}
\hline Material & Process & $\begin{array}{c}\text { Yield stress } \\
\text { [MPa] }\end{array}$ & $\begin{array}{l}\text { Apparent bend } \\
\text { strength }[\mathrm{MPa}]\end{array}$ & $\begin{array}{c}\text { SiC } \\
\text { YS increase } \\
\text { [MPa] }\end{array}$ & $\begin{array}{c}\text { Drawing } \\
\text { YS increase } \\
\text { [MPa] }\end{array}$ \\
\hline $\mathrm{Al}$ & \multirow{3}{*}{ Extrusion } & 70 & 221 & - & - \\
\hline $\mathrm{Al}-5 \% \mathrm{SiC}$ & & 74 & 238 & 4 & - \\
\hline $\mathrm{Al}-10 \% \mathrm{SiC}$ & & 83 & 267 & 13 & - \\
\hline $\mathrm{Al}$ & \multirow{3}{*}{$\begin{array}{l}\text { Extrusion and } \\
\text { drawing }\end{array}$} & 100 & 271 & - & 30 \\
\hline $\mathrm{Al}-5 \% \mathrm{SiC}$ & & 115 & 285 & 15 & 31 \\
\hline $\mathrm{Al}-10 \mathrm{t} \% \mathrm{SiC}$ & & 122 & 309 & 22 & 39 \\
\hline $\mathrm{Al}-5 \% \mathrm{SiC}$ & Further 2 passes & 150 & - & - & 50 \\
\hline Alloy & \multirow{2}{*}{ Extrusion } & 220 & 675 & - & - \\
\hline Alloy-5\% $\%$ SiC & & 280 & 600 & 60 & - \\
\hline Alloy & \multirow{2}{*}{$\begin{array}{l}\text { Extrusion and } \\
\text { age-hardening }\end{array}$} & 380 & 926 & - & - \\
\hline Alloy-5\% $\%$ SiC & & 390 & 773 & 10 & - \\
\hline
\end{tabular}




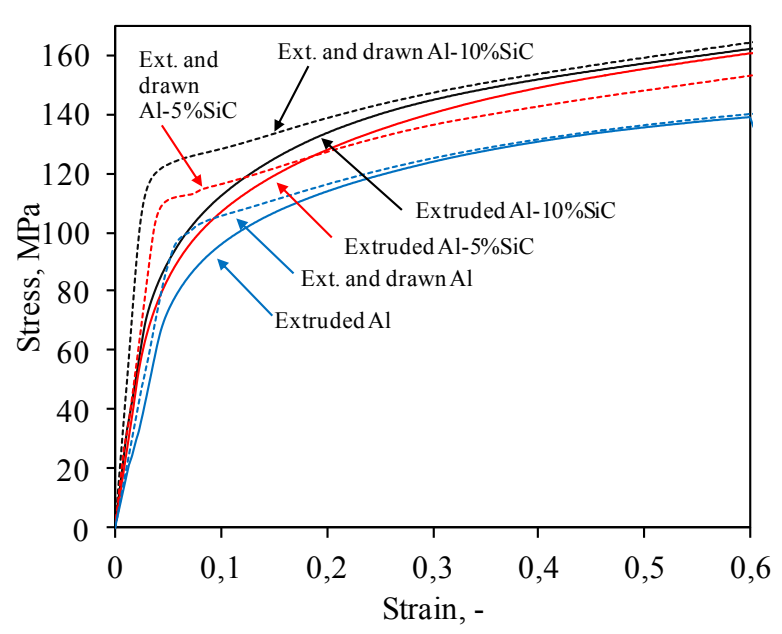

a)

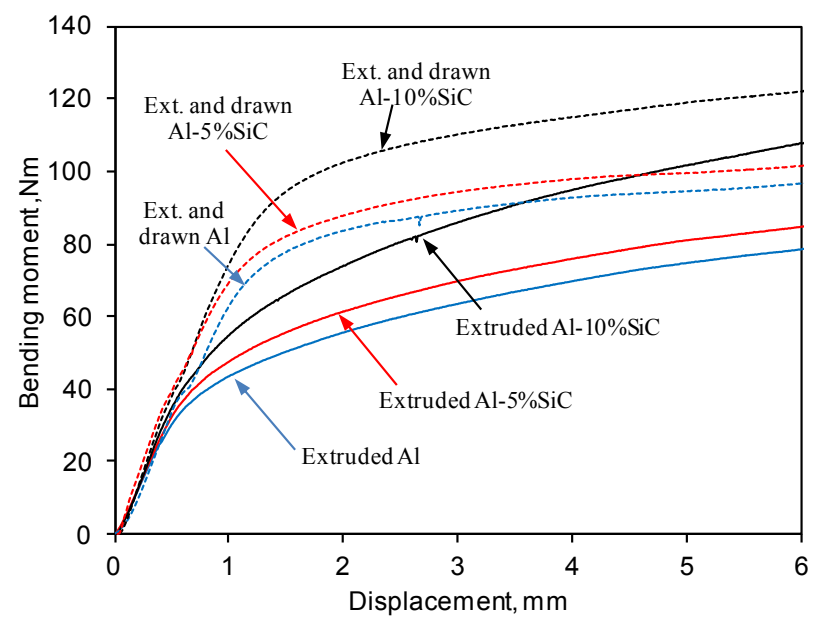

b)

Fig. 5. a) Stress - compressive strain relationships and b) bending moment vs displacement diagram of extruded and extruded and drawn (1 pass) materials Al, Al-SiC composite (Ext- extruded)

Small particles of SiC were observed on fractures of failed bend specimens acting as stress concentrators for cracking (Fig. 4b, c). Al matrix fracture surfaces were ductile. Fractures of Al$10 \% \mathrm{SiC}$ appeared more brittle than in $\mathrm{Al}-5 \% \mathrm{SiC}$. Near the surface layer of drawn materials a deformation zone appeared.

\section{Discussion}

The expected increase in Young's modulus of Al due to the much stiffer SiC particles was demonstrated. For every material almost $30 \%$ improvement in hardness were obtained after drawing. Strengthening of the composite by drawing (one pass) after extrusion has clearly been shown (Table 2). Second subsequent passes resulted in further $35 \mathrm{MPa}$ increase in the yield strength. Cold working of aluminium matrix influenced strengthening more than SiC particle content. Table 2 lists also some of our previous data in an attempt to identify the various contributions to overall strengthening of $\mathrm{Al}$ and $\mathrm{Al}-18.8 \mathrm{Cu}-6.3 \% \mathrm{Si}-0.7 \mathrm{Mg}$ alloy [10]. Some possible contributions to strengthening of aluminium are illustrated on Fig. 6.

It appears that alloying and age-hardening have the greatest effect. Possible contributions from hot, warm and cold working, however, are not insignificant. It is proposed that the higher stress values, up to $50 \mathrm{MPa}$, in drawn $\mathrm{Al}-\mathrm{SiC}$ materials result from strain hardening of the aluminium matrix and dislocation blocking on particles. As powder metallurgy processing is an important fabrication method, their incorporation into the processing schedule merits consideration.

The hot extrusion and drawing of model $\mathrm{Al}$ and $\mathrm{Al}-\mathrm{X} \% \mathrm{SiC} \mathrm{PM}$ materials have shown manufacturing possibility of obtaining products with nearly full density and useful strength properties. The strengthening properties depend on the chemical composition of the preforms, the processing route and its parameters. As a result of cold drawing, sizing of the diameter of the product and cold working of the matrix take place. 


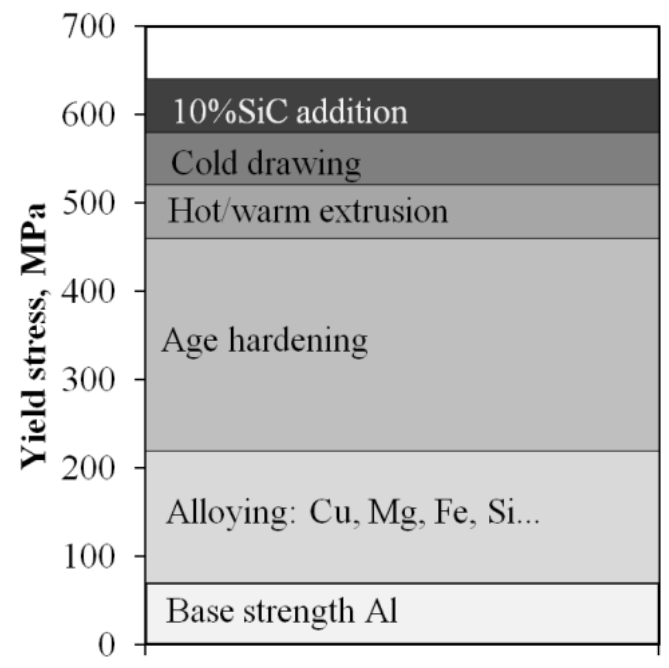

Fig. 6. Possible contributions to strengthening of aluminium

\section{Acknowledgements}

This research forms of the AGH in Krakow Statutory Work Program No. 11.11.110.292 in year 2016.

\section{References}

[1] F. Erdemir, A. Canakci, T. Varol, Microstructural characterization and mechanical properties of functionally graded A12024/SiC composites prepared by powder metallurgy techniques, Trans. of Nonfer. Met. Soc. China 25 (2015) 3569-3577

[2] A. J. Knowles, X. Jiang, M. Galano, F. Audebert, Microstructure and mechanical properties of $6061 \mathrm{Al}$ alloy based composites with SiC nanoparticles, J. Alloys. Compd. 615 (2014) 401-405

[3] M. De Giovanni, J. M. Warnett, M. A. Williams, N. Haribabu, P. Srirangam, X-ray tomography investigation of intensive sheared Al-SiC metal matrix composites, Mat. Char. 110 (2005) 258-263

[4] C. Xue, H. Bai, P. F. Tao, J. W. Wang, N. Jiang, S. L. Wang, Thermal conductivity and mechanical properties of flake graphite/Al composite with a SiC nano-layer on graphite surface, Mat. \& Des. 108 (2016) 250-258

[5] W. Li, H. Liang, J. Chen, S. Q. Zhu, Y. L. Chen, Effect of SiC particles on fatigue crack growth behavior of SiC particulate-reinforced Al-Si alloy composites produced by spray forming, Procedia Mat. Sci. 3 (2014) 1694-1699

[6] P. B Li, T. J Chen, Effect of reheating temperature on the microstructure and tensile properties of SiCP/2024Al composite prepared by powder thixoforming, Powder Metall. 59 (2016) 288-300

[7] S. Szczepanik, Light PM aluminium based composite reinforced with SiC particles processed by closed-die forging and extrusion, Rudy i Metale Nieżelazne 58 (2013) 692-697

[8] S. Szczepanik, M. Wojtaszek, P. Nikiel, Aluminum and Al-SiC composite processed by closeddie forging of powders, Rudy i Metale Nieżelazne 56 (2011) 390-396

[9] B. I. Mordike, K. U. Kainer, Bauteile aus pulvermetallurgisch hergestellten LeichtmetallKurzfaser-Verbundwerkstoffen, Neue Werkstoffe, Band I, VDI Berichte 670 (1988) 285-300

[10] Kształtowanie z udziałem fazy ciekłej stopów i kompozytów aluminiowych wzmocnionych cząstkami. Raport nr 4 T08D 007 23. AGH Kraków, 2005 